\title{
ANALYSIS OF EDUCATORS AND EDUCATION STAFF MANAGEMENT IN PRIMARY SCHOOL QUALITY IMPROVEMENT
}

\author{
Cucun Sunaengsih*a, Jamil Jatnika ${ }^{b}$, Silvy Lafthi Alifia ${ }^{c}$, Latifah $^{d}$, Endang Solihah ${ }^{\mathrm{e}}$ \\ abcde Primary Teacher Education Study Program, Indonesia University of Education, in Sumedang Campus \\ Jl. Mayor Abdurahman No.211, Sumedang, West Java, Indonesia \\ $\underline{\text { cucunsunaengsih@upi.edu }}^{*}{ }^{* a}$, jamiljatnika99@upi.edu ${ }^{\mathrm{b}}, \underline{\text { silvylafthialifia@upi.edu }}^{\mathrm{c}}, \underline{\text { latifah22@ @upi.edu }}^{\mathrm{d}}$, \\ endangsolihah@upi.edu ${ }^{\mathrm{e}}$
}

\begin{abstract}
Educators and education staff are primary aspects of education that contribute to school quality improvement. Highquality educators and education staff will lead to high-quality school. However, not all educators and education staff have good quality, due to low-quality management. With this in mind, this study aims to discover the implementation of educators and education staff management in a primary school in West Java, Indonesia. It is found that (1) the ideal ratio of educators and staff has not been achieved, (2) temporary educators are far from being prosperous, in terms of monetary compensation, and (3) training programs for educators and education staff are very limited. These finding indicate that the planning and development process for educators and education staff require an in-depth analysis.
\end{abstract}

Keywords: Management, quality, educators, education staff, primary school

\section{INTRODUCTION}

The quality of national education can be measured by the achievement of all national education standards, which include the standards of content, process, graduates' competencies, educators and education staff (Manshur, 2012). Serious consideration, from all parties involved, on the efforts to satisfy and realize all these standards will determine the quality of education in the nation. The quality of education is always a hot and interesting topic to be discussed and studied. Quality of education is in line with the demand for development and change (Serrat, 2009). A change requires active roles of agents of change to produce ideas of improvement and to manage the changes (Scott, 2003). Education is a field that plays strategic role in improving the quality of people in a nation (Bush, 2007). Improving quality in education implementation requires knowledge of education system management which can answer the challenges in education. One of the challenges in education is the problem of educators and education staff management (Greenlee \& Ed, 2015).

Education is a process to develop individuals to possess knowledge, skills, attitude, and technology that can change a bad situation into a better, higher in quality, and more meaningful condition (Kirman, 1992). Education which is implemented directly by educators (teachers, lecturers, instructors, tutors) as a process plays a crucial role and cannot be replaced by technology, no matter how sophisticated it is (Brush \& Saye, 2009).

Various studies and reviews have been done by experts in education, who conclude that quality of education greatly depends on the roles of 


\section{Cucun Sunaengsih, et al. /Journal of Educational Administration Research and Review / \\ Vol. 3 No.1 June 2019}

education resources, including human resources or staff that directly perform their tasks and functions (Priyanka, Meenu, \& Harish kumar, 2015). One of the most dominant resources in education is educators and education staff who interact directly with students as part of their duties and responsibilities to realize educational goals (Okoye \& Ezejiofor, 2013). Functionally speaking, educators and education staff support each other so that their synergic role can create a more harmonious and dynamic educational situation to achieve educational objectives (Taylor, Eric S and Tyler, 2012).

The success of education system implementation is greatly affected by the quality of educators and education staff. In an institution that provides education, at any level, one of the most important aspect to focus on is how educators and education staff management is implemented in accordance with laws and regulations, because both elements are determining factors of how education is implemented in our nation (Greenlee \& Ed, 2012). The two elements of human resources are interrelated and are an inseparable system. Quality of education is closely related to the demand for development and change. A change requires active roles of agents of change to produce ideas of improvement and to manage the changes. Our study is different from previous studies because it looks at three aspects that affect the quality of education. The general aim of this study is how educators and education staff management are implemented in primary school quality improvement efforts

\section{METHODS}

The present study is a qualitative study, in which the researcher formulates a complex description, analyzes words and detailed accounts from respondents, and conducts a study in a natural setting based on a method that investigates a social phenomenon and human problems. Qualitative study is a suitable approach to describe the management of educators and education staff in SDN Pasanggrahan I, Sumedang, West Java, Indonesia. Data is collected through observation and interviews and is analyzed using descriptive data analysis. The subject of this study is the headmaster of SDN Pasanggrahan I.

\section{RESULTS AND DISCUSSION}

This study yields several findings. Based on data analysis, SDN Pasanggrahan $\mathrm{I}$ is quite good in managing its educators and education staff, which positively affects the resulted quality of education. The public school is able to perform its function to develop creative and innovative human resources.

The findings of this study are:

1. Ineffective procurement (recruitment) of educators and education staff.

2. Lack of training and development programs for educators and education staff.

3. Low compensation for temporary educators and staff.

Based on these findings, it is concluded that SDN Pasanggrahan I has an extensive staff administration system. Staff administration is the most basic process in gathering information pertaining to staffing system. Staff administration gathers and provides information about individuals' general administration requirements. Staff administration in SDN Pasanggrahan I consists of staff data, staff's daily presence list, data recapitulation of organizational structure, staff's letter of assignment or permit of absence, staff's records of leaves, staff assessment data, master data of staff, and archive of staff's files.

Staff procurement or recruitment is the preliminary step in recruiting new staff. It starts with the announcement of acceptance based on available formation (posts). Staff are accepted based on the kind of work, position, and educational qualification required for each position (Rolfe, 2012). Before recruitment or procurement of staff, staffing plan is formulated (Okoye \& Ezejiofor, 2013). At this stage, need analysis is conducted to map how many staff is required for each vacant post in 


\section{Cucun Sunaengsih, et al. /Journal of Educational Administration Research and Review / Vol. 3 No.1 June 2019}

the organizational structure. The analysis involves various aspects, including age limit. In SDN Pasanggrahan I, there are 18 educators and 2 education staff. The researcher concludes that SDN Pasanggrahan I has excessive number of educators and insufficient number of education staff.

The researcher arrives at this conclusion by considering the number of classes in SDN Pasanggrahan I. The school has six classrooms, accommodating six grades. If each grade is divided into two classes (grade $1 \mathrm{a}$ and $\mathrm{b}$, and so on), and if each class needs one educator, the school only needs 12 educators. On the other hand, the education staff is lacking in SDN Pasanggrahan I because there are only two staff; an operator and a gatekeeper. The operator also functions as homeroom teacher and the gatekeeper doubles as janitor. There are several facilities in the school that have not been managed properly, such as the infirmary and the library. The school needs two or three more staff to work as janitor, librarian, and nurse. This finding indicates that there was an error in need analysis of staffing during the planning stage. Hence, staff recruitment or procurement is not effective.

Development is an effort to maintain the staff in an organization. It is a follow up to recruitment, after which the staff are placed in certain position in accordance with the required formation and the staff's qualification in the education institution (Borko, 2004). Educators and staff development aims intended to ensure that they provide the best service in their job (Hannon, 2008). Educators and staff development can be done through education and training programs, compensation distribution, salary, welfare packages, promotion, assessment, and paid leaves.

Development is conducted to manage and control the staff during their tenure in the institution/school. SDN Pasanggrahan I only provides one development program for educators, i.e. Teachers' Work Group (KKG). The headmaster participates in a development program called Headmasters' Work Group (K3S). The school does not provide any development program for education staff, however. Thus, the researcher concludes that the headmaster is not up to date with latest information about development programs. There are many development programs for education staff available. Even though the operator can enroll in computer and data processing trainings, the school has never sent him to participate in any development program.

Compensation is given by the Office of Education and the school to educational staff for their works. Compensation is usually in monetary form and tends to be regularly given (Cibulka, 2009). In addition to salary, compensation can be in the forms of benefits, housing facilities, vehicles, et cetera. For educators who are government employees (civil servants), the compensation is given directly by the government. Meanwhile, compensation for temporary educators is allocated from School's Operational Grant. The welfare of temporary educators and staff is a problem that has not been fully resolved to this day. This is also true in the case of temporary staff in SDN Pasanggrahan I, whose welfare is far from adequate.

The success of education in schools depends greatly on the success of the headmaster in managing educators and staff in his/her school (Keskes, 2013). To achieve such success, an analysis of educators and education staff procurement (recruitment) is necessary. In addition, the school, via the headmaster, should provide development programs that suit the skills needed by educators in the age of 4.0 revolution. These two activities are required if the school wants to improve the quality of its education.

The headmaster plays a big role in managing educators and staff to improve the quality of education in his/her school (Berendt, Christofi, Kasibhatla, Malindretos, \& Maruffi, 2012). Education quality improvement involves not only educators, who determine the quality of education in the school, it also involves the headmaster. Headmaster's role in education quality improvement is crucial. As a leader of a school, headmaster is required to be able to 
build and develop the education institution into an excellent school. Through educators and education staff management, headmasters must play their roles by considering that: 1) educators' and staff's skills and capabilities need to always be improved and developed through various development programs that the government provides; 2) teachers' welfare needs to be improved, particularly in terms of compensation for temporary teachers; 3) a more rigorous selection process is needed in the procurement or recruitment stage so that the quality and quantity of educators and education staff suit the need of the school (Borko, 2004).

\section{CONCLUSION/RECOMENDATION}

Based on those findings and interviews with the headmaster of SDN Pasanggrahan I, it is concluded that educators and staff management in SDN Pasanggrahan I is generally good. However, there are certain aspects that need to be improved. For instance, compensation for temporary educators and training programs for educators and staff require some major improvement. It is because they affect education quality. School's function is to develop human resources (students) to be better and education quality is reflected in the quality of the graduates. Since quality of education depends on the quality of educators and staff. Educators' and staff's quality will determine the quality of education process in the school. Education process may go well, may be average, or even far from the expectation; all of which will dictate the quality of education in that school. Hence, educators and staff management are crucial for an education process. If the management go well, the teaching and learning process in that school will go well too. Educators and staff management has a linear correlation with the resulting graduates. In many schools, both public and private, headmasters are unable to perform good management, which harm the quality of education in those schools. In conclusion, the quality of education in a school is determined by the successful management of human resources, among others.

\section{REFERENCES (Examples)}

Berendt, C. J., Christofi, A., Kasibhatla, K. M., Malindretos, J., \& Maruffi, B. (2012). Transformational leadership: Lessons in management for today. International Business Research, 5(10), 227-232. https://doi.org/10.5539/ibr.v5n10p227

Blatchford, P., Bassett, P., \& Brown, P. (2009). The effect of support staff on pupil engagement and individual attention. British Educational Research Journal, 35(5), 661-686. https://doi.org/10.1080/01411920902878917

Borko, H. (2004). Professional Development and Teacher Learning: Mapping the Terrain. Educational Researcher, 33(November), 3-15.

Brush, T., \& Saye, J. W. (2009). Strategies for preparing preservice social studies teachers to integrate technology effectively: models and practices. Contemporary Issues in Technology and Teacher Education, 9, 46-59.

Bush, T. (2007). Educational leadership and management: theory, policy, and practice. South African Journal of Education, 27, 391$406 . \quad$ Retrieved from http://www.sajournalofeducation.co.za/index.p hp/saje/article/view/107/29

Cibulka, J. G. (2009). Alternative certification. Education Next, Vol. 9, pp. 7-8.

Greenlee, B. J., \& Ed, D. (2012). Building Teacher Leadership Capacity through Educational Leadership Programs. Journal of Research for Educational Leaders, 4(1), 44-74.

Greenlee, B. J., \& Ed, D. (2015). Building Teacher Leadership Capacity through Educational Leadership Programs. Journal of Research for Educational Leaders, 4(1), 44-74.

Hannon, J. (2008). Doing staff development : Practices, dilemmas and technologies. Australasian Journal of Educational Technology, 24(1), 1529.

Keskes, I. (2013). Relationship between leadership styles and dimensions of employee organizational commitment: A critical review and discussion of future directions. Intangible Capital, 10(1), 26-51. https://doi.org/org/10.3926/ic.476

Kirman, J. M. U. O. A. (1992). Values, Technology, and Social Studies. McGill Journal of Education, 27(1), 5-18. Retrieved from http://mje.mcgill.ca/index.php/MJE/article/vie w/8011/5939

Manshur. (2012). Penerapan Sistem Nilai Dalam Budaya Organisasi Sekolah Unggul: Studi Multikasus. Cakrawala Pendidikan, 3(1), 512-523.

Okoye, P. V. C., \& Ezejiofor, R. a. (2013). The Effect of Human Resources Development on Organizational Productivity. International Journal of Academic Research in Business and Social Sciences, 3(10), 250-269. https://doi.org/10.6007/IJARBSS/v3-i10/295

Priyanka, Meenu, \& Harish kumar. (2015). Recent Trends in Human Resources. Golden Research Thoughts, 4(12), 1-17. https://doi.org/10.9780/22315063

Rolfe, V. (2012). Open educational resources: staff attitudes and awareness. Research in Learning Technology, 20(1063519), 1-13. https://doi.org/10.3402/rlt.v20i0/14395 
Scott, G. (2003). Effective Change Management in Higher Education. Educause Review, 38, 6480. Retrieved from http://www.educause.edu/EDUCAUSE+Revie w/EDUCAUSEReviewMagazineVolume38/Ef fectiveChangeManagementinHig/157869
Serrat, B. O. (2009). A Primer on Organizational Culture. Sustainable Development, (November), 1-6.

Siemens, G. (2014). Connectivism: A Learning Theory for the Digital Age. International Journal of Instructional Technology and Distance Learning, 1, 1-8. https://doi.org/10.1.1.87.3793

Taylor, Eric S and Tyler, J. H. (2012). Can Teacher Evaluation Improve Teaching? Education Next, 12, 78-84. 